\title{
Kondisi Keuangan dan Lingkungan Terhadap Kepatuhan Wajib Pajak Orang Pribadi
}

\author{
Agustina Fatima dan Priyo Hari Adi
}

Fakultas Ekonomika dan Bisnis Universitas Kristen Satya Wacana (UKSW) Salatiga

J1. Diponegoro No. 52-60 Salatiga 50711, Indonesia

\section{Info Article}

Keywords:

Environmental; Financial conditions; and Tax compliance

ISSN (print) : 2598-7763

ISSN (online): 2598-7771

$\triangle$ Corresponding Author: Agustina Fatima:

Tel. /Fax. 085747478060

E-mail: ema.agustina96@gmail.com

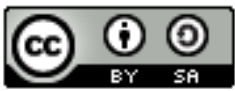

\begin{abstract}
Abtract
Tax compliance is the attitude of someone who shows that they are obedient in fulfilling their tax obligations, based on rules and regulations in taxation. This study aims to determine the effect of financial conditions and environmental on the compliance of individual taxpayers in paying land and building tax in Salatiga city. The object of this research is the individual taxpayer who is charged for land and building tax in Salatiga. The method used in the research is multiple regression test, to see the effect of financial conditions and environmental on compliance in paying land and building taxes. The data source used is primary data, which is obtained through disturbing questionnaires directly to respondents. The results of this study provide evidence that financial conditions and environmental affect the compliance of individual taxpayers in paying land and building taxes in the city of Salatiga

Citation: Fatima, Agustina dan Adi Hari Priyo (2019). Kondisi Keuangan dan Lingkungan Terhadap Kepatuhan Wajib Pajak Pribadi. Accounting and Financial Review, 2 (2)
\end{abstract}

\begin{abstract}
Abstraks
Kepatuhan pajak adalah sikap seseorang yang menunjukkan bahwa mereka patuh dalam memenuhi kewajiban pajaknya, berdasarkan aturan dan ketentuan dalam perpajakan. Penelitian ini bertujuan untuk mengetahui pengaruh kondisi keuangan dan lingkungan terhadap kepatuhan wajib pajak orang pribadi dalam membayar pajak bumi dan bangunan di Kota Salatiga. Objek penelitian ini adalah wajib pajak orang pribadi yang dikenakan atas pajak bumi dan bangunan di Kota Salatiga. Metode yang digunakan dalam penelitian adalah uji regresi berganda untuk melihat pengaruh kondisi keuangan dan lingkungan terhadap kepatuhan dalam membayar pajak bumi dan bangunan. Sumber data yang digunakan yaitu data primer, yang diperoleh melalui penyebaran kuesioner secara langsung kepada responden. Hasil penelitian ini memberikan bukti bahwa kondisi keuangan dan lingkungan berpengaruh terhadap kepatuhan wajib pajak orang pribadi dalam membayar pajak bumi dan bangunan di Kota Salatiga
\end{abstract}

JEL Classification G31, G32

DOI: https:/ / doi.org/10.26905/afr.v2i2.3172

\section{PENDAHULUAN}

Pajak merupakan sumber pembiayaan yang penting bagi negara (Herlan dan Chasbiandani, 2019). Salah satu pajak adalah Pajak Bumi dan Bangunan (PBB). PBB memiliki peran penting dalam hal pembangunan nasional. Hasil dari penerimaan PBB yang dibayarkan oleh masyarakat kepada pemerintah, nantinya akan kembali pada masyarakat itu sendiri melalui pembangunan infrastruktur di masing-masing daerah (Fitrianingsih, Sudarno, \& Kurrohman, 2018). PBB yang awalnya merupakan tanggung jawab Pemerintah Pusat (DJP), saat ini sudah beralih menjadi pajak daerah, yang menjadi tanggung jawab bagi Pemerintah Kabupaten/Kota. Hal ini tercantum dalam Undang-Undang Nomor 28 Tahun 2009 tentang Pajak Daerah dan Retribusi Daerah, yang menjelaskan mengenai PBB yang saat ini menjadi 
pajak daerah.

Berdasarkan Undang-undang Nomor 28 Tahun 2009 tersebut PBB sebagai pajak daerah dengan wewenang Pemerintah Kabupaten/Kota. Pemerintah Kabupaten/Kota bertanggung jawab penuh atas keberhasilan sektor PBB, baik dalam hal pemungutan pembayaran PBB maupun penagihan tunggakan PBB yang belum dibayarkan wajib pajak (WP), agar dapat mencapai penerimaan sesuai target yang telah ditetapkan (Widiastuti \& Laksito, 2014). Untuk mencapai keberhasilan tersebut, dapat dilakukan melalui peran pemerintah Kabupaten/Kota untuk meningkatkan minat dan kepatuhan masyarakat dalam rangka pembayaran PBB (Aryati, 2012).

Namun demikian, sebagian besar daerah masih menemui kendala dikarenakan tidak tercapainya target penerimaan dari pajak ini, salah satunya adalah pemerintah Kota Salatiga. Harian Tribun Jateng pada 18 April 2017, memberikan informasi adanya tunggakan PBB di Kota Salatiga yang nilainya Rp. 5,3 Milyar. Tunggakan PBB tersebut menjadi tanggung jawab Pemerintah Kota Salatiga untuk melakukan tagihan atas tunggakan pajak yang belum dibayarkan kepada WP. Jumlah tunggakan yang bernilai Rp. 5,3 Milyar ini merupakan hasil akumulasi dari beberapa tahun sebelumnya, tidak hanya pada tahun 2016 (Setiawan, 2017).

Adanya tunggakan pajak yang bernilai cukup besar tersebut, kemungkinan terjadi karena rendahnya kepatuhan WP dalam memenuhi kewajiban perpajakan, sehingga WP enggan untuk membayar pajak (Binambuni, 2013). Rendahnya kepatuhan seseorang dalam pembayaran pajak bisa disebabkan karena faktor internal (seperti kesadaran individu untuk membayar kewajiban pajaknya, pengetahuan dan pemahaman individu mengenai pentingnya pajak, kondisi keuangan WP dan sebagainya) maupun faktor eksternal (seperti lingkungan WP, kualitas pelayanan pajak, adanya kepastian hukum yang kuat, sosialisasi yang diberikan dan sebagianya) (Putri \& Jaka, 2013).

Penelitian terdahulu telah dilakukan terkait dengan determinan kepatuhan WP PBB. Beberapa faktor penting telah diteliti dan memiliki indikasi terhadap kepatuhan dalam pembayaran PBB yaitu tingkat pendapatan WP dan lingkungan WP. Hal ini dikarenakan jumlah pajak terutang yang harus dibayarkan setiap orang akan tergantung pada pendapatan mereka, jika pendapatan yang mereka miliki dapat mencukupi kebutuhan hidup dan memungkinkan untuk membayar pajak, ma- ka hal tersebut akan memudahkan para pelaku pajak untuk memenuhi kewajiban pajaknya (Amran, 2018). Selain itu, lingkungan yang mendukung adanya pelaksanaan pajak berpengaruh terhadap peningkatan perilaku patuh pajak. Jika masyarakat di lingkungan WP patuh dalam melaksanakan pembayaran pajak, hal tersebut akan mendorong masyarakat lain untuk ikut patuh dalam membayar pajak (Liyani, Masitoh, \& Samrotun, 2017).

Berdasarkan penelitian sebelumnya mengenai kepatuhan WP terhadap pembayaran PBB, peneliti ingin melakukan penelitian lebih lanjut mengenai kepatuhan PBB di Kota Salatiga. Dalam penelitian ini, peneliti ingin menguji mengenai pengaruh kondisi keuangan dan lingkungan terhadap kepatuhan wajib pajak orang pribadi (WPOP) dalam membayar PBB di Kota Salatiga. Tujuan dilakukannya penelitian ini adalah guna mengetahui pengaruh kondisi keuangan dan lingkungan terhadap kepatuhan WPOP dalam membayar PBB di Kota Salatiga

\section{PENGEMBANGAN HIPOTESIS}

\section{Kondisi Keuangan Terhadap Kepatuhan WPOP Dalam Membayar PBB}

Kondisi keuangan merupakan kondisi yang menunjukkan kemampuan ekonomi individu dalam memenuhi segala kebutuhan hidupnya, dengan menggunakan pendapatan yang mereka miliki (Purwanto, Harimurti, \& Astuti, 2015). Selain, pendapatan, kondisi keuangan juga dapat diketahui dari kemampuan individu untuk memenuhi kebutuhan hidupnya, apakah WP membutuhkan bantuan dari pihak lain berupa pinjaman atau tidak. Kondisi ini dapat diketahui melalui jumlah pendapatan yang dimiliki WP, besarnya pengeluaran WP, ada atau tidaknya pinjaman yang dimiliki, serta kemampuan ekonomi WP dalam memenuhi segala kebutuhan hidupnya. Jika seorang individu mampu memenuhi segala kebutuhan hidupnya secara mandiri dengan pendapatan yang WP miliki tanpa bantuan dari pihak lain, maka individu tersebut tergolong dalam individu yang memiliki kondisi keuangan yang baik, dan begitu sebaliknya.

Kondisi keuangan dapat mempengaruhi kepatuhan dalam pembayaran pajak, salah satunya dalam pembayaran PBB. Kepatuhan pajak itu sendiri merupakan sikap patuh dalam memenuhi kewajiban pajak berdasarkan ketentuan, yang sesuai dengan undang-undang perpajakan (Wulandari \& Suyanto, 2014). Setiap WP yang 
memiliki tanah dan bangunan akan dikenakan pajak sesuai dengan nilai objek pajaknya, dan WP bertanggung jawab untuk memenuhi kewajiban tersebut. Hal ini dikarenakan hasil penerimaan yang diperoleh dari pembayaran PBB, sepenuhnya akan digunakan untuk pembangunan infrastruktur di masing-masing daerah (Budhiartama \& Jati 2016). Namun kenyataannya, tidak semua WP yang memiliki tanah dan bangunan dapat mencukupi kebutuhan pajaknya. WP yang memiliki tanah dan bangunan dengan nilai pajak yang tinggi, belum tentu memiliki kon-disi keuangan yang baik, yang sebanding dengan nilai pajak atas tanah dan bangunan yang dimilikinya.

Penelitian Ayunda (2015) menjelaskan bahwa tingkat ekonomi yang tinggi akan mendorong pelaku pajak untuk patuh dalam pembayaran PBB. Seseorang dengan tingkat ekonomi yang baik akan cenderung lebih patuh untuk memenuhi kewajiban pajaknya, dan begitu sebaliknya. Dalam penelitian lain membuktikan jika terdapat indikasi antara tingkat pendapatan individu dengan kepatuhan pajak. Setiap individu dengan tingkat pendapatan yang tinggi, mereka akan lebih patuh untuk membayar pajak. Namun sebaliknya, individu dengan tingkat pendapatan yang rendah dan tidak memungkinkan untuk melakukan pembayaran pajak, mereka akan menjadi tidak patuh pajak (Amran, 2018). Hal ini dikarenakan, setiap individu akan lebih mengutamakan untuk memenuhi kebutuhan mereka terlebih dahulu dibandingkan untuk kebutuhan lainnya, termasuk dalam membayar pajak.

$\mathrm{H}_{1}$ : Kondisi keuangan berpengaruh positif terhadap kepatuhan WPOP dalam membayar PBB.

\section{Lingkungan Terhadap Kepatuhan WPOP Dalam Membayar PBB}

Lingkungan merupakan faktor di sekitar individu, yang secara langsung ataupun tidak langsung dapat mempengaruhi pandangan dan perilaku individu dalam melakukan suatu aktivitas (Jotopurnomo \& Mangoting, 2013). Lingkungan ini dapat berupa interaksi antar satu individu dengan individu lain, yang akan menimbulkan keterbukaan antar individu di lingkungan tersebut. Dalam hal kepatuhan pajak, keter-bukaan antar individu terkait dengan sikap terbuka untuk mengkomunikasikan sesuatu yang terkait pajak dan perilaku mereka dalam memenuhi kewajiban pajaknya, apakah mereka termasuk dalam WP yang mendukung pelaksanaan pajak atau sebaliknya. Jika lingkungan WP mendukung pelaksanaan pajak agar masyarakatnya patuh $\mathrm{p}$ ajak, hal tersebut akan berdampak pada kepatuhan pajak yang semakin tinggi (Liyani et al., 2017).

Lingkungan WP dapat terjalin melalui hubungan yang paling dekat yaitu dengan keluarga, teman, masyarakat setempat, sera lingkungan tempat WP bekerja (Jotopurnomo \& Mangoting, 2013). Hubungan antar WP yang terjalin melalui interaksi di lingkungan dapat memberikan pengaruh terhadap pandangan dan perilaku masing-masing WP dalam melakukan suatu tindakan, termasuk perilaku patuh atau tidak patuhnya WP terhadap kewajiban perpajakannya (Jotopurnomo \& Mangoting, 2013). WP yang awalnya sudah patuh dalam pembayaran pajak, bisa berubah menjadi tidak patuh pajak karena WP lain di lingkungan sekitarnya ternyata banyak yang tidak patuh untuk membayar pajak, sehingga mereka akan melakukan tindakan yang sama. Sebaliknya, WP akan menjadi patuh pajak jika WP lain di sekitarnya mendukung pelaksanaan pajak dan patuh dalam pembayaran pajak (Jotopurnomo \& Mangoting, 2013).

Hal ini sesuai dengan penelitian Liyani et al (2017) yang membuktikan bahwa faktor lingkungan WP dapat mendorong perilaku individu untuk patuh terhadap pembayaran pajak. Lingkungan dengan kondisi yang kondusif akan lebih mendukung individu untuk bertindak patuh dalam pembayaran pajak. Jika lingkungan WP mendukung adanya pelaksanaan perpajakan, maka kepatuhan pajak akan semakin meningkat, dan begitu pula sebaliknya. Dalam penelitian lain juga membuktikan jika terdapat indikasi antara lingkungan WP berada dengan kepatuhan pajak. Jika masyarakat di lingkungan sekitar WP termasuk dalam masyarakat yang patuh pajak, maka pela$\mathrm{ku}$ pajak lain yang berada di lingkungan tersebut akan ikut bertindak untuk patuh dalam melakukan pembayaran pajak (Jotopurnomo \& Mangoting, 2013).

$\mathrm{H}_{2}$ : Lingkungan berpengaruh positif terhadap kepatuhan WPOP dalam membayar PBB.

\section{DATA DAN METODE}

Jenis penelitian ini merupakan penelitian kuantitatif, yaitu dalam penelitian akan dilakukan olah data dengan menggunakan metode statistik yang bertujuan untuk melakukan pengujian terhadap hipotesis yang telah disusun. Sumber data dalam penelitian menggunakan data primer, yaitu data-data yang dibutuhkan dalam penelitian 
diperoleh melalui responden dengan penyebaran kuesioner kepada responden secara langsung. Kuesioner dalam penelitian ini dikembangkan dari penelitian sebelumnya yang dilakukan oleh Jotopurnomo dan Mangoting (2013); Ernawati (2014).

Dalam penelitian ini, populasi yang menjadi sumber data adalah semua WPOP yang dikenakan atas PBB di Kota Salatiga. Sampel dalam penelitian diperoleh dengan menggunakan teknik Cluster Random Sampling, yaitu sampel akan diperoleh dengan pembagian responden dari setiap Kecamatan yang ada di Kota Salatiga, yang meli- puti Kecamatan Tingkir, Argomulyo, Sidomukti dan Sidorejo. Dari beberapa kecamatan tersebut akan diperoleh 120 responden, dengan kriteria yaitu responden merupakan WPOP yang dikenakan atas PBB di Kota Salatiga.

Variabel dependen dalam penelitian ini adalah kepatuhan WPOP dalam membayar PBB. Dalam melakukan pengukuran terhadap kepatuhan WP, peneliti menggunakan aspek kondisi keuangan dan lingkungan, yang merupakan variabel independen. Operasionalisasi variabel penelitian disajikan pada Tabel 1.

Tabel 1 Definisi Operasional Variabel

\begin{tabular}{|c|c|c|}
\hline Variabel & Definisi operasional & Indikator \\
\hline $\begin{array}{l}\text { Kondisi Keuangan Wajib Pajak } \\
\left(X_{1}\right)\end{array}$ & $\begin{array}{l}\text { Suatu kondisi yang menunjukkan tingkat } \\
\text { ekonomi WP dalam memenuhi segala kebu- } \\
\text { tuhan hidupnya, dengan menggunakan pen- } \\
\text { dapatan yang mereka miliki (Purwanto, } \\
\text { Harimurti, dan Astuti, 2015). }\end{array}$ & $\begin{array}{l}\text { 1. Pendapatan yang diperoleh WP } \\
\text { 2. Pendapatan lain atau tambahan } \\
\text { yang diperoleh } \\
\text { 3. Pinjaman WP } \\
\text { 4. Pendapatan untuk menabung }\end{array}$ \\
\hline Lingkungan Wajib Pajak $\left(X_{2}\right)$ & $\begin{array}{l}\text { Faktor di sekitar WP, yang secara langsung } \\
\text { maupun tidak langsung dapat mempengaruhi } \\
\text { pandangan dan perilaku WP dalam melakukan } \\
\text { suatu aktivitas (Jotopurnomo dan Mangoting, } \\
\text { 2013). }\end{array}$ & $\begin{array}{l}\text { 1. Pengaruh keluarga } \\
\text { 2. Pengaruh teman } \\
\text { 3. Pengaruh tetangga atau masyara- } \\
\text { kat setempat }\end{array}$ \\
\hline Kepatuhan Wajib Pajak (Y) & $\begin{array}{l}\text { Sikap WP yang menunjukkan bahwa WP patuh } \\
\text { dalam memenuhi kewajiban pajak berdasarkan } \\
\text { ketentuan, yang sesuai dengan undang-undang } \\
\text { perpajakan (Aryati, 2012). }\end{array}$ & $\begin{array}{l}\text { 1. Kesediaan WP untuk membayar } \\
\text { PBB sesuai ketentuan } \\
\text { 2. WP membayar PBB sesuai dengan } \\
\text { jumlah pajak terutang yang harus } \\
\text { dibayar } \\
\text { 3. Ketepatan waktu dalam membayar } \\
\text { pajak sebelum jatuh tempo } \\
\text { 4. WP tidak memiliki tunggakan } \\
\text { pajak } \\
\text { 5. WP bersedia melaporkan kepemi- } \\
\text { likan bumi dan bangunan kepada } \\
\text { pemerintah }\end{array}$ \\
\hline
\end{tabular}

Teknik analisis data digunakan regresi berganda. Regresi berganda dilakukan dengan tujuan untuk menguji apakah masing-masing variabel bebas mempunyai pengaruh terhadap variabel terikat dalam penelitian. Untuk mengetahui pengaruh antar variable bebas dengan variable terikat, pada pengujian ini akan dirumuskan dengan persamaan sebagai berikut:

$$
Y=\alpha+\beta X_{1}+\beta X_{2}+\varepsilon
$$

Keterangan: $Y=$ Kepatuhan WP; $\alpha=$ konstansa; $\beta=$ Koefisien regresi; $X_{1}=$ Kondisi keuangan $W P ; X_{2}=$ Lingkungan WP; dan $\varepsilon=$ error

\section{HASIL}

\section{Uji Validitas}

Berdasarkan hasil pengujian validitas menunjukkan instrument valid. Hasil uji validitas data ditampilkan pada tabel 2. Berdasarkan hasil uji validitas pada tabel 18, dapat diketahui pada tabel 2 bahwa nilai correlation dari setiap item pertanyaan menunjukkan nilai lebih besar dari 0.179 . Dengan demikian, dapat disimpulkan bahwa setiap item pertanyaan yang digunakan dalam kuesioner merupakan data penelitian yang valid.

\section{Uji Reliabilitas}

Pengujian reliabilitas dilakukan dengan cara membandingkan nilai Cronbach Alpha dengan nilai minimal 0,6 . Data penelitian dinyatakan reliabel apabila nilai Cronbach Alpha dari hasil pengujian mnunjukkan nilai lebih besar dari 0,6. Hasil uji reliabilitas data ditampilkan pada tabel 3. Berdasarkan hasil pengujian menunjukkan reliabel. 
Tabel 2 Ringkasan Hasil Uji Validitas

\begin{tabular}{rcccc}
\hline Variabel & Item & Correlation & Standart & Keterangan \\
\hline Kondisi Keuangan (X1) & X1.1 & 0,733 & 0,179 & Valid \\
& X1.2 & 0,738 & 0,179 & Valid \\
& X1.3 & 0,448 & 0,179 & Valid \\
& X1.4 & 0,594 & 0,179 & Valid \\
Lingkungan (X2) & X1.5 & 0,760 & 0,179 & Valid \\
& X2.1 & 0,728 & 0,179 & Valid \\
& X2.2 & 0,716 & 0,179 & Valid \\
X2.3 & 0,786 & 0,179 & Valid \\
& X2.4 & 0,755 & 0,179 & Valid \\
& X2.5 & 0,796 & 0,179 & Valid \\
Kepatuhan (Y) & Y1 & 0,784 & 0,179 & Valid \\
& Y2 & 0,862 & 0,179 & Valid \\
& Y3 & 0,774 & 0,179 & Valid \\
& Y4 & 0,827 & 0,179 & Valid \\
& Y5 & 0,846 & 0,179 & Valid \\
& & & 0,179 & Valid \\
\hline
\end{tabular}

Tabel 3 Ringkasan Hasil Uji Reliabilitas

\begin{tabular}{lcc}
\hline \multicolumn{1}{c}{ Variabel } & Cronbach Alpha & Keterangan \\
\hline Kondisi Keuangan $(\mathrm{X} 1)$ & 0,757 & Reliabel \\
Lingkungan $(\mathrm{X} 2)$ & 0,791 & Reliabel \\
Kepatuhan $(\mathrm{Y})$ & 0,807 & Reliabel \\
\hline
\end{tabular}

Jumlah sampel semula berdasarkan kuesioner yang disebarkan kepada responden yaitu sebanyak 150 orang, tetapi dari jumlah tersebut responden yang memenuhi kriteria dalam penelitian ini hanya berjumlah 120 responden. Kriteria yang digunakan dalam penelitian ini yaitu WPOP yang dikenakan atas PBB di Kota Salatiga. Responden yang tidak memenuhi kriteria tersebut yaitu responden yang tidak melakukan pembayaran atas PBB di Kota Salatiga. Sehingga jumlah sampel dalam penelitian ini sejumlah 120 .

\section{Analisis Distribusi Frekuensi}

\section{Kondisi Keuangan}

Pendapat WPOP terhadap kondisi keuangan terbagi dalam lima bagian (Tabel 4). Berdasarkan hasil analisis pada tabel 4 untuk variabel kondisi keuangan, diketahui pada indikator 1 menunjukkan jika sebagian besar responden sejumlah 49 orang $(40,83 \%)$ berpendapat sangat setuju. Jumlah tersebut menunjukkan bahwa sebagian besar WP memiliki pendapatan tetap setiap bulannya. Pada indikator 2, menunjukkan jika sebagian besar responden sejumlah 63 orang $(52,5 \%)$ berpendapat setuju. Jumlah tersebut menunjukkan bahwa sebagian besar pendapatan yang diperoleh WP dapat mencukupi kebutuhan sehari-hari. Pada indikator 3 , menunjukkan jika sebagian besar responden sejumlah 57 orang $(47,5 \%)$ berpendapat setuju. Jumlah tersebut menunjukkan bahwa sebagian besar WP memiliki pendapatan tambahan dalam waktu tertentu. Pada indikator 4, menunjukkan jika sebagian responden sejumlah 58 orang $(48,33 \%)$ berpendapat setuju. Jumlah tersebut menunjukkan bahwa sebagian besar WP memiliki pinjaman yang harus dibayar setiap bulannya. Pada indikator 5, menunjukkan jika sebagian besar responden sejumlah 42 orang (35\%) berpendapat setuju. Jumlah tersebut menunjukkan bahwa sebagian besar WP menabung setiap bulannya.

Tabel 4 Distribusi Frekuensi Indikator Variabel Kondisi Keuangan

\begin{tabular}{|c|c|c|c|c|c|c|}
\hline \multirow{2}{*}{ No } & \multirow{2}{*}{ Indikator } & \multicolumn{5}{|c|}{ Frekuensi (Jumlah dan Presentase) } \\
\hline & & STS & TS & $\mathrm{N}$ & $\mathrm{S}$ & SS \\
\hline \multirow[t]{2}{*}{1.} & WP memiliki pendapatan tetap setiap bulan & 1 & 22 & 10 & 38 & 49 \\
\hline & & $(0,83 \%)$ & $(18,33 \%)$ & $(8,33 \%)$ & $(31,67 \%)$ & $(40,83 \%)$ \\
\hline \multirow[t]{2}{*}{2.} & Pendapatan WP cukup untuk memenuhi kebutuhan & 0 & 13 & 18 & 63 & 26 \\
\hline & sehari-hari & $(0 \%)$ & $(10,83 \%)$ & $(15 \%)$ & $(52,5 \%)$ & $(21,67 \%)$ \\
\hline \multirow[t]{2}{*}{3.} & WP memiliki pendapatan lain atau tambahan dalam & 9 & 19 & 20 & 57 & 15 \\
\hline & waktu tertentu & $(7,5 \%)$ & $(15,83 \%)$ & $(16,67 \%)$ & $(47,5 \%)$ & $(12,5 \%)$ \\
\hline \multirow[t]{2}{*}{4.} & WP memiliki pinjaman yang harus dibayar setiap & 11 & 17 & 13 & 58 & 21 \\
\hline & bulan & $(9,17 \%)$ & $(14,17 \%)$ & $(10,83 \%)$ & $(48,33 \%)$ & $(17,5 \%)$ \\
\hline
\end{tabular}




\begin{tabular}{llccccc}
\hline 5. & WP menabung setiap bulan & 7 & 19 & 26 & 42 & 26 \\
& & $(5,83 \%)$ & $(15,83 \%)$ & $(21,67 \%)$ & $(35 \%)$ & $(21,67 \%)$ \\
\hline
\end{tabular}

\section{Lingkungan}

Pendapat WPOP terhadap lingkungan terbagi dalam enam bagian (Tabel 5). Berdasarkan hasil analisis pada tabel 3 untuk variabel lingkungan, diketahui pada indikator 1 menunjukkan jika sebagian besar responden sejumlah 54 orang (45\%) berpendapat setuju. Jumlah tersebut menunjukkan jika sebagian besar keluarga WP menanamkan perilaku taat pajak. Pada indikator 2, menunjukkan jika sebagian besar responden sejumlah 60 orang (50\%) berpendapat setuju. Jumlah tersebut menunjukkan jika sebagian besar kelurga WP melakukan pembayaran pajak secara tepat waktu. Pada indikator 3, menunjukkan jika sebagian besar responden sejumlah 64 orang $(53,33 \%)$ berpendapat setuju. Jumlah tersebut menunjukkan jika sebagian besar keluarga
WP selalu mengingatkan untuk membayar pajak. Pada indikator 4, menunjukkan jika sebagian besar responden sejumlah 54 orang (45\%) berpendapat setuju. Jumlah tersebut menunjukkan jika sebagian besar teman dari WP menginformasikan kewajiban warga Negara untuk membayar pajak. Pada indikator 5, menunjukkan jika sebagian besar responden sejumlah 58 orang $(48,33 \%)$ berpendapat setuju. Jumlah tersebut menunjukkan jika sebagian besar teman dari WP mengingatkan untuk membayar pajak. Pada indikator 6, menunjukan jika sebagian besar responden sejumlah 65 orang $(54,16 \%)$ berpendapat setuju. Jumlah tersebut menunjukkan jika sebagian besar tetangga di sekitar WP merupakan masyarakat yang mendukung pelaksanaan pajak.

Tabel 5 Distribusi Frekuensi Indikator Variabel Lingkungan

\begin{tabular}{|c|c|c|c|c|c|c|}
\hline \multirow{2}{*}{ No. } & \multirow{2}{*}{ Indikator } & \multicolumn{5}{|c|}{ Frekuensi (Jumlah dan Presentase) } \\
\hline & & STS & TS & $\mathrm{N}$ & $\mathrm{S}$ & SS \\
\hline 1. & Keluarga menanamkan perilaku taat pajak & $\begin{array}{c}0 \\
0 \% \\
(0 \%)\end{array}$ & $\begin{array}{c}7 \\
(5,83 \%)\end{array}$ & $\begin{array}{c}12 \\
(10 \%)\end{array}$ & $\begin{array}{c}54 \\
(45 \%)\end{array}$ & $\begin{array}{c}47 \\
(39,17 \%)\end{array}$ \\
\hline 2. & $\begin{array}{l}\text { Keluarga selalu membayar pajak tepat } \\
\text { waktu }\end{array}$ & $\begin{array}{c}1 \\
(0,83 \%)\end{array}$ & $\begin{array}{c}3 \\
(2,5 \%)\end{array}$ & $\begin{array}{c}17 \\
(14,17 \%)\end{array}$ & $\begin{array}{c}60 \\
(50 \%)\end{array}$ & $\begin{array}{c}39 \\
(32,5 \%)\end{array}$ \\
\hline 3. & $\begin{array}{l}\text { Keluarga selalu mengingatkan untuk mem- } \\
\text { bayar pajak }\end{array}$ & $\begin{array}{c}0 \\
(0 \%)\end{array}$ & $\begin{array}{c}5 \\
(4,17 \%)\end{array}$ & $\begin{array}{c}17 \\
(14,17 \%)\end{array}$ & $\begin{array}{c}64 \\
(53,33 \%)\end{array}$ & $\begin{array}{c}34 \\
(28,33 \%)\end{array}$ \\
\hline 4. & $\begin{array}{l}\text { Teman menginformasikan membayar pajak } \\
\text { adalah kewajiban warga negara }\end{array}$ & $\begin{array}{c}1 \\
(0,83 \%)\end{array}$ & $\begin{array}{c}5 \\
(4,17 \%)\end{array}$ & $\begin{array}{c}28 \\
(23,33 \%)\end{array}$ & $\begin{array}{c}54 \\
(45 \%)\end{array}$ & $\begin{array}{c}32 \\
(26,67 \%)\end{array}$ \\
\hline 5. & $\begin{array}{l}\text { Teman mengingatkan untuk membayar } \\
\text { pajak }\end{array}$ & $\begin{array}{c}4 \\
(3,33 \%)\end{array}$ & $\begin{array}{c}9 \\
(7,5 \%)\end{array}$ & $\begin{array}{c}29 \\
(24,17 \%)\end{array}$ & $\begin{array}{c}58 \\
(48,33 \%)\end{array}$ & $\begin{array}{c}20 \\
(16,67 \%)\end{array}$ \\
\hline 6. & $\begin{array}{l}\text { Tetangga atau masyarakat setempat men- } \\
\text { dukung pelaksanaan pajak }\end{array}$ & $\begin{array}{c}2 \\
(1,67 \%)\end{array}$ & $\begin{array}{c}3 \\
(2,5 \%)\end{array}$ & $\begin{array}{c}27 \\
(22,5 \%)\end{array}$ & $\begin{array}{c}65 \\
(54,16 \%)\end{array}$ & $\begin{array}{c}23 \\
(19,17 \%)\end{array}$ \\
\hline
\end{tabular}

Berdasarkan hasil analisis pada tabel 5 untuk variabel lingkungan, diketahui pada indikator 1 menunjukkan jika sebagian besar responden sejumlah 54 orang (45\%) berpendapat setuju. Jumlah tersebut menunjukkan jika sebagian besar keluarga WP menanamkan perilaku taat pajak. Pada indikator 2, menunjukkan jika sebagian besar responden sejumlah 60 orang (50\%) berpendapat setuju. Jumlah tersebut menunjukkan jika sebagian besar kelurga WP melakukan pembayaran pajak secara tepat waktu. Pada indikator 3, menunjukkan jika sebagian besar responden sejumlah 64 orang $(53,33 \%)$ berpendapat setuju. Jumlah tersebut menunjukkan jika sebagian besar keluarga WP selalu mengingatkan untuk membayar pajak. Pada indikator 4, menunjukkan jika sebagian besar responden sejumlah 54 orang (45\%) berpendapat setuju. Jumlah tersebut menunjukkan jika sebagian besar teman dari WP menginformasikan kewajiban warga Negara untuk membayar pajak. Pada indikator 5 , menunjukkan jika sebagian besar responden sejumlah 58 orang $(48,33 \%)$ berpendapat setuju. Jum- lah tersebut menunjukkan jika sebagian besar teman dari WP mengingatkan untuk membayar pa

jak. Pada indikator 6, menunjukan jika sebagian besar responden sejumlah 65 orang $(54,16 \%)$ berpendapat setuju. Jumlah tersebut menunjukkan jika sebagian besar tetangga di sekitar WP merupakan masyarakat yang mendukung pelaksanaan pajak.

\section{Kepatuhan Wajib Pajak}

Pendapat WPOP terkait kepatuhan WP terhadap PBB terbagi dalam lima bagian (Tabel 6). Berdasarkan hasil analisis pada tabel 6, diketahui pada indikator 1 menunjukkan jika sebagian besar responden sejumlah 66 orang (55\%) berpendapat setuju. Jumlah tersebut menunjukkan jika sebagian besar WP melakukan pembayaran PBB sesuai dengan ketentuan. Pada indikator 2, menunjukkan jika sebagian besar responden sejumlah 63 orang $(52,5 \%)$ berpendapat setuju. Jumlah tersebut menunjukkan jika sebagian besar WP melakukan pembayaran PBB sesuai dengan jumlah pajak terutang. Pada indikator 3, menunjukkan jika sebagian 
besar responden sejumlah 63 orang $(52,5 \%)$ berpendapat setuju. Jumlah tersebut menunjukkan jika sebagian besar WP melakukan pembayaran pajak sebelum jatuh tempo pada SPPT. Pada indikator 4, menunjukkan jika sebagian besar responden sejumlah 57 orang $(47,5 \%)$ berpendapat setuju. Jumlah tersebut menunjukkan jika sebagian besar WP tidak memiliki tunggakan atas PBB. Pada indikator
5, menunjukkan jika sebagian besar responden sejumlah 59 orang $(49,17 \%)$ berpendapat setuju. Jumlah tersebut menunjukkan jika sebagian besar WP bersedia untuk melaporkan kepemilikan bumi dan bangunan. Dari hasil analisis tersebut, dapat disimpulkan bahwa sebagian besar responden merupakan WP yang patuh pajak.

Tabel 6 Distribusi Frekuensi Indikator Variabel Kepatuhan WP

\begin{tabular}{|c|c|c|c|c|c|c|}
\hline \multirow{2}{*}{ No. } & \multirow{2}{*}{ Indikator } & \multicolumn{5}{|c|}{ Frekuensi (Jumlah dan Presentase) } \\
\hline & & STS & TS & $\mathrm{N}$ & $S$ & SS \\
\hline 1. & $\begin{array}{l}\text { WP bersedia membayar Pajak Bumi dan } \\
\text { Bangunan sesuai ketentuan }\end{array}$ & $\begin{array}{c}0 \\
(0 \%)\end{array}$ & $\begin{array}{c}2 \\
(1,67 \%)\end{array}$ & $\begin{array}{c}7 \\
(5,83 \%)\end{array}$ & $\begin{array}{c}66 \\
(55 \%)\end{array}$ & $\begin{array}{c}45 \\
(37,5 \%)\end{array}$ \\
\hline 2. & $\begin{array}{l}\text { WP membayar Pajak Bumi dan Bangunan } \\
\text { sesuai dengan jumlah pajak terutang }\end{array}$ & $\begin{array}{c}0 \\
(0 \%)\end{array}$ & $\begin{array}{c}2 \\
(1,67 \%)\end{array}$ & $\begin{array}{c}8 \\
(6,67 \%)\end{array}$ & $\begin{array}{c}63 \\
(52,5 \%)\end{array}$ & $\begin{array}{c}47 \\
(39,16 \%)\end{array}$ \\
\hline 3. & $\begin{array}{l}\text { WP membayar Pajak Bumi dan Bangunan } \\
\text { sebelum jatuh tempo yang tertera pada } \\
\text { SPPT }\end{array}$ & $\begin{array}{c}0 \\
(0 \%)\end{array}$ & $\begin{array}{c}2 \\
(1,67 \%)\end{array}$ & $\begin{array}{c}13 \\
(10,83 \%)\end{array}$ & $\begin{array}{c}63 \\
(52,5 \%)\end{array}$ & $\begin{array}{c}42 \\
(35 \%)\end{array}$ \\
\hline 4. & $\begin{array}{l}\text { WP tidak memiliki tunggakan atas Pajak } \\
\text { Bumi dan Bangunan }\end{array}$ & $\begin{array}{c}3 \\
(2,5 \%)\end{array}$ & $\begin{array}{c}5 \\
(4,17 \%)\end{array}$ & $\begin{array}{c}12 \\
(10 \%)\end{array}$ & $\begin{array}{c}57 \\
(47,5 \%)\end{array}$ & $\begin{array}{c}43 \\
(35,83 \%)\end{array}$ \\
\hline 5. & $\begin{array}{l}\text { WP bersedia melaporkan informasi perihal } \\
\text { kepemilikan bumi dan bangunan kepada } \\
\text { pemerintah }\end{array}$ & $\begin{array}{c}0 \\
(0 \%)\end{array}$ & $\begin{array}{c}3 \\
(2,5 \%)\end{array}$ & $\begin{array}{c}16 \\
(13,33 \%)\end{array}$ & $\begin{array}{c}59 \\
(49,17 \%)\end{array}$ & $\begin{array}{c}42 \\
(35 \%)\end{array}$ \\
\hline
\end{tabular}

\section{Uji Asumsi Klasik}

Sebelum dilakukan uji regresi, terlebih dahulu dilakukan uji asumsi klasik yang meliputi uji normalitas, multikolinearitas dan heteroskedastisitas. Berdasarkan pengujian yang dilakukan diketahui bahwa data penelitian berdistribusi normal, tidak terdapat multikolinearitas antar variabel dan tidak terjadi gejala heteroskedastisitas. Dengan demikian, data penelitian dapat dinyatakan lolos un tuk semua uji asumsi klasik karena telah memenuhi kriteria yang ditentukan.

\section{Uji Regresi Berganda}

Uji regresi berganda dilakukan untuk mengetahui apakah terdapat pengaruh dari variabel bebas (variabel independen) terhadap variabel terikat (variabel dependen). Hasil uji regresi berganda ditampilkan pada table 7 .

Tabel 7 Ringkasan Hasil Uji Regresi

\begin{tabular}{lcccc}
\hline \multicolumn{1}{c}{ Variabel } & beta & $\mathrm{t}$ & $\mathrm{Sig}$ & Keterangan \\
\hline (konstanta) & 7,194 & 4.693 & 0.000 & \\
Kondisi Keuangan (X1) & 0,280 & 4.616 & 0.000 & H1 Diterima \\
Lingkungan (X2) & 0,367 & 6.424 & 0.000 & H2 Diterima \\
Adjusted R square & & 0,406 & & \\
\hline
\end{tabular}

\section{Pengujian Hipotesis}

Berdasarkan pengujian yang dilakukan, diketahui bahwa nilai signifikan variabel kondisi keuangan (X1) terhadap kepatuhan PBB menunjukkan jika H1 diterima. Hal ini memberikan bukti bahwa kondisi keuangan memiliki pengaruh yang signifikan terhadap kepatuhan WPOP dalam membayar PBB. Artinya, semakin baik kondisi keuangan WP maka akan semakin tinggi tingkat kepatuhan PBB. Hasil uji variabel lingkungan (X2) terhadap kepatuhan PBB juga menunjukkan jika H2 diterima. Hal ini memberikan bukti bahwa lingkungan memiliki pengaruh yang signifikan terhadap kepatuhan WPOP dalam membayar PBB. Artinya, jika lingkungan WP merupakan WP yang mendukung pelaksanaan pajak, maka tingkat ke-

patuhan PBB akan semakin tinggi.

Selanjutnya, selain melihat nilai signifikan dari masing-masing variabel juga diketahui nilai Adjusted $\mathrm{R}$ square untuk mengetahui presentase seberapa besar pengaruh dari variabel independen terhadap kepatuhan dalam pembayaran PBB. Berdasarkan hasil uji tersebut, dapat diketahui bahwa pengaruh variabel kondisi keuangan dan lingkungan terhadap kepatuhan PBB adalah sebesar $40,6 \%$, sedangkan sisanya sebesar 59,4\% dipengaruhi oleh variabel lain di luar penelitian ini.

\section{PEMBAHASAN}




\section{Kondisi Keuangan Terhadap Kepatuhan WPOP Dalam Membayar PBB}

Berdasarkan hasil analisis diketahui bahwa variabel kondisi keuangan memiliki pengaruh yang signifikan terhadap kepatuhan WPOP dalam membayar PBB. Hasil tersebut menunjukkan bahwa semakin baik kondisi keuangan individu, maka akan berdampak pada semakin tinggi tingkat kepatuhan pajak. Hasil penelitian ini mendukung penelitian Amran (2018) yang menunjukkan hasil bahwa semakin tinggi tingkat pendapatan yang diperoleh individu, maka akan mendorong perilaku patuh pajak yang berdampak pada semakin tinggi tingkat kepatuhan pajak dalam pembayaran PBB. Apabila seseorang memiliki kondisi keuangan yang baik serta mampu memenuhi segala kebutuhan hidupnya secara mandiri, maka mereka akan cenderung untuk lebih patuh dalam membayar pajak. Begitu juga sebaliknya, jika seseorang sedang mengalami kondisi keuangan yang kurang baik dan tidak memungkinkan untuk membayar pajak, bukan tidak mungkin mereka akan melalaikan kewajibannya terhadap pembayaran pajak (Ayunda, 2015). Hal ini dikarenakan setiap individu akan lebih mengutamakan untuk memenuhi segala kebutuhan hidupnya terlebih dahulu dibandingkan kebutuhan lainnya, termasuk dalam pembayaran pajak.

\section{Lingkungan Terhadap Kepatuhan WPOP Dalam Membayar PBB}

Berdasarkan hasil analisis diketahui bahwa variabel lingkungan memiliki pengaruh signifikan terhadap kepatuhan WPOP dalam membayar PBB. Hasil tersebut menunjukkan bahwa lingkungan yang mendukung pelaksanaan pajak akan berdampak pada kepatuhan pajak yang semakin tinggi. Hasil penelitian ini mendukung penelitian Liyani et al (2017) yang menyatakan bahwa lingkungan yang kondusif akan lebih mendukung individu untuk bertindak patuh dalam pembayaran PBB. Penelitian ini juga mendukung penelitian (Jotopurnomo \& Mangoting, 2013) yang memberikan hasil bahwa lingkungan WP berada berpengaruh signifikan terhadap kepatuhan WPOP. Hal ini dikarenakan hubungan antar WP yang terjalin di lingkungan mereka dapat mempengaruhi pandangan dan perilaku WP dalam melakukan suatu tindakan, termasuk dalam perilaku untuk patuh ataupun tidak patuh terhadap pelaksanaan pajak. Sehingga apabila lingkungan di sekitar WP merupakan individu yang mendukung pelaksanaan pajak, hal tersebut akan mendorong pelaku pajak lain untuk ikut bertindak patuh dalam pembayaran pajak, dan begitu juga sebaliknya (Jotopurnomo \& Mangoting, 2013).

\section{SIMPULAN DAN SARAN}

Penelitian ini bertujuan untuk mengetahui pengaruh kondisi keuangan dan lingkungan terhadap kepatuhan WPOP dalam membayar PBB di Kota Salatiga. Berdasarkan hasil analisis dan pembahasan di atas, dapat diketahui bahwa dalam penelitian ini memberikan bukti jika variabel kondisi keuangan dan lingkungan memberikan pengaruh signifikan terhadap kepatuhan WPOP dalam melakukan pembayaran PBB di Kota Salatiga.

Keterbatasan dalam penelitian ini yaitu dalam penyebaran kuesioner kepada responden jumlahnya belum merata untuk setiap kecamatan, hal ini dikarenakan tidak semua responden bersedia untuk mengisi kuesioner dan adanya keterbatasan waktu dalam mencari data. Pada penelitian mendatang, peneliti diharapkan dapat menjalin relasi dan komunikasi lebih baik lagi, terutama dengan pihakpihak yang berhubungan dengan objek penelitian yang akan digunakan. Dengan melakukan hal tersebut, nantinya akan lebih me-mudahkan peneliti dalam pengambilan data. Sehingga ke depannya hasil penelitian dapat sesuai dengan apa yang diharapkan.

Secara keseluruhan, kondisi keuangan dan lingkungan WPOP memiliki pengaruh terhadap kepatuhan dalam membayar PBB. Untuk itu, diperlukan adanya partisipasi dari pihak terkait untuk dapat memberikan sosialisasi kepada WP mengenai pentingnya membayar $\mathrm{PBB}$, yang nantinya akan digunakan dalam pembangunan infrstruktur di masing-masing daerah. Dengan demikian, jika WP mengerti akan pentingnya PBB diharapkan WP dapat semakin patuh dalam membayar pajak.

\section{DAFTAR PUSTAKA}

Amran. (2018). Pengaruh Sanksi Perpajakan, Tingkat Pendapatan Dan Kesadaran Wajib Pajak Terhadap Kepatuhan Wajib Pajak Orang Pribadi. Jurnal Ilmiah Akuntansi, 1 (1): $1-15$.

Aryati, T. (2012). Analisis Faktor - Faktor Yang Mempengaruhi Tingkat Kepatuhan Wajib Pajak Badan. Media Ekonomi Dan Manajemen, 25 (1): 13-29.

Ayunda, W. P. (2015). Pengaruh Sanksi Perpajakan, Pengetahuan Pajak, Sikap Wajib Pajak, dan Tingkat Ekonomi Terhadap Kepatuhan Wajib Pajak Badan Dalam Membayar Pajak 
Bumi dan Bangunan Dengan Kontrol Petugas Kelurahan Sebagai Variabel Moderating Di Kota Pekanbaru. Jom FEKON, 2 (2): 1-15.

Binambuni, D. (2013). Sosialisasi PBB Pengaruhnya Terhadap Kepatuhan Terhadap Wajib Pajak Di Desa Karatung Kecamatan Nanusa Kabupaten Talaud. Jurnal EMBA, 1 (4): 20782087.

Budhiartama, I. G. P., \& Jati, I. K. (2016). Pengaruh Sikap, Kesadaran Wajib Pajak dan Pengetahuan Perpajakan Pada Kepatuhan Membayar Pajak Bumi dan Bangunan. EJurnal Akuntansi Universitas Udayana, 15: 1510-1535.

Fitrianingsih, F., Sudarno, \& Kurrohman, T. (2018). Analisis Pengaruh Pengetahuan Perpajakan, Pelayanan Fiskus Dan Sanksi Denda Terhadap Kepatuhan Wajib Pajak Dalam Membayar Pajak Bumi Dan Bangunan Perdesaan Dan Perkotaan Di Kota Pasuruan (Analysis Effect Of Taxation Knowledge, Government Services And S. E-Journal Ekonomi Bisnis Dan Akuntansi, 5 (1): 100-104.

Herlan dan Chasbiandani, Tryas (2019). Tax Avoidance Jangka Panjang di Indonesia. AFRE Accounting and Financial Review, 2 (1): 73-80

Jotopurnomo, C., \& Mangoting, Y. (2013). Pengaruh Kesadaran Wajib Pajak, Kualitas Pelayanan Fiskus, Sanksi Perpajakan, Lingkungan Wajib Pajak Berada terhadap Kepatuhan Wajib Pajak Orang Pribadi di Surabaya. Tax $\mathcal{E}$ Accounting Review, 1 (1): 50-54.

Liyani, A., Masitoh, E., \& Samrotun, Y. C. (2017). Faktor Faktor Yang Mempengaruuhi Kepatuhan Wajib Pajak Dalam Membayar Pajak Bumi dan Bangunan Di Desa GebangHarjo, Pracimantoro, Wonogiri. Seminar Nasional IENACO: 817-824.

Purwanto, W., Harimurti, F., \& Astuti, D. S. P. (2015). Pengaruh Tingkat Ekonomi, Pengetahuan Pajak dan Kepercayaan Masyarakat Terhadap Kepatuhan Pajak Bumi dan Bangunan Dengan Kontrol Petugas Desa Sebagai Variabel Moderating. Jurnal Akuntansi Dan Sistem Teknologi Informasi, 11: 293-303.

Putri, C. D. S., \& Jaka, I. (2013). Ekonomi, dan Pengetahuan Pajak Terhadap Kepatuhan PBB Masyarakat Desa dan Kota Dengan Variabel Moderating Kontrol Petugas Desa / Kelurahan (Studi Kasus Pada Kabupaten Demak). Diponegoro Journal of Accounting, 2
(3): 1-11.

Setiawan, D. (2017). Pemkot Salatiga Peroleh Limpahan Tunggakan PBB Hingga Rp 5,3 Miliar.

Undang-Undang Republik Indonesia No. 28 Tahun 2009 Tentang Pajak Daerah dan Retribusi Daerah. , (2009).

Widiastuti, R., \& Laksito, H. (2014). Faktor-Faktor Yang Mempengaruhi Kepatuhan Pajak Bumi dan Bangunan (P-2) (Studi pada WPOP di Kabupaten Klaten). Diponegoro Journal of Accounting, 3 (2): 1-15.

Wulandari, T., \& Suyanto. (2014). Pengaruh Pengetahuan Perpajakan, Tingkat Pendidikan dan Sanksi Administrasi Terhadap Kepatuhan Wajib Pajak Dalam Melakukan Pembayaran Pajak Bumi dan Bangunan (Studi Kasus Pada Kantor Dinas Pendapatan Daerah Kabupaten Sleman). Jurnal Akuntansi, 2 (2): 94-102. 